\title{
Comunicação
}

[Communication]

\section{Hepatite granulomatosa em bovino causada por Mycobacterium avium subsp. paratuberculosis}

[Granulomatous hepatitis in cattle caused by Mycobacterium avium subsp. paratuberculosis]

\author{
A.B.F. Rodrigues ${ }^{1}$, P. Ristow ${ }^{2}$, A.S.O. Santos ${ }^{3}$, W. Lilenbaum ${ }^{4}$, L.S. Fonseca ${ }^{5}$, \\ C.B. Carvalho ${ }^{1}$, E.C.Q. Carvalho ${ }^{1}$ \\ ${ }^{1}$ Universidade Estadual do Norte Fluminense Darcy Ribeiro - UENF \\ 28013-602 - Campos dos Goytacazes, RJ \\ ${ }^{2} \mathrm{CPqGM} /$ FIOCRUZ - Rio de Janeiro, RJ \\ ${ }^{3}$ Instituto Federal de Educação do Pará - Belém, PA \\ ${ }^{4}$ Universidade Federal Fluminense - Niterói, RJ \\ ${ }^{5}$ Universidade Federal do Rio de Janeiro - Rio de Janeiro, RJ
}

A paratuberculose bovina é uma enterite crônica granulomatosa de ruminantes domésticos e silvestres. O agente etiológico, Mycobacterium avium subsp. paratuberculosis (Map), é um microrganismo intracelular facultativo e álcool ácido resistente. Os bovinos se infectam principalmente no período neonatal, mas as manifestações clínicas dificilmente aparecem em animais com idade inferior a dois anos (Chiodini et al., 1984). As principais lesões da paratuberculose ocorrem no intestino delgado e são caracterizadas, macroscopicamente, por espessamento da mucosa, que assume um aspecto corrugado, semelhante às circunvoluções cerebrais, e por linfadenomegalia mesentérica (Ristow et al., 2007). Os achados histopatológicos consistem de enterite, linfangite e linfadenite granulomatosas epitelioides e não gigantocitárias, associadas a bacilos álcool ácido resistentes (BAAR) em macrófagos (Chiodini et al., 1984). Hepatites granulomatosas pelo Map em ovinos e bovinos foram descritas por Mahmound et al. (2002) e Driemeier et al. (1990), respectivamente.

Os testes utilizados para diagnosticar a paratuberculose podem ser divididos em duas principais categorias: métodos para a detecção do agente e métodos de detecção de anticorpos específicos presentes no soro (Buergelt e Ginn, 2000), no entanto o isolamento de Map em meio de cultura contendo micobactina permanece como padrão ouro de diagnóstico. Sabe-se que é importante a dosagem da aspartato amino transferase (AST) na avaliação de possíveis danos ao fígado e aos músculos esquelético e cardíaco. A mensuração de gama glutamil transferase (GGT), segundo Roussel et al. (1997), representa um dos testes mais específicos para avaliação da função hepática na medicina veterinária.

Este trabalho se propôs a relatar e discutir o conjunto de lesões macro e microscópicas, em amostras de intestinos, linfonodos mesentéricos e, principalmente, fígado, um achado incomum, de um caso de paratuberculose bovina. Um bovino de aproximadamente dois anos e meio de idade, Girolando, oriundo de uma propriedade leiteira em Resende, RJ, há um ano vinha apresentando episódios de diarreia e perda de peso progressivos, sem melhora clínica em resposta à terapia com antibióticos e antihelmínticos. O animal estava caquético, edemaciado, apático e com diarreia líquida com muco. Apesar disso, apresentava apetite normal. À palpação retal, revelava acentuada sensibilidade (dor) abdominal. A sorologia para o ELISA-PPA era fortemente reativa. Antes da eutanásia e necropsia, $10 \mathrm{~mL}$ de sangue foram colhidos da veia caudal em frasco sem anticoagulante. Do material enviado ao

Recebido em 26 de fevereiro de 2010

Aceito em 19 de novembro de 2010

E-mail: zana@uenf.br 
laboratório e centrifugado a 6.000rpm por cinco minutos, retirou-se o soro, que foi identificado e congelado a $-20^{\circ} \mathrm{C}$, para posteriores análises bioquímicas. Nestas foram dosadas AST e GGT em espectrofotômetro computadorizado e semiautomático Microlab 200 (Merck S.A.) usando-se os kits comerciais Gold Analisa Diagnóstica.

Amostras de intestinos (duodeno, jejuno, íleo e válvula ileocecal), linfonodos mesentéricos e fígado foram colhidas, fixadas em formol neutro tamponado a $10 \%$ e remetidas para processamento por inclusão em parafina, cortes em micrótomo rotativo a $5 \mu \mathrm{m}$ e coloração por hematoxilina-eosina e Zihel-Neelsen (ZN) para a deteç̧ão de BAAR. Os tecidos foram submetidos à imunoistoquímica (IHQ) para evidenciação do bacilo utilizando-se anticorpo primário policlonal de coelho anti-M. bovis policlonal (Dako, EUA), na diluição de 1:6000. Foi utilizado o kit da marca Dako LSA+, e as lâminas foram processadas conforme protocolo geral do autocorador da marca Dako (Autostain), segundo especificação do fabricante. A coloração foi revelada após a incubação das lâminas com a solução cromógena à base de diaminobenzidina (DAB).

Amostras de intestinos, linfonodos mesentéricos e fígado também foram congeladas a $-20^{\circ} \mathrm{C}$ e enviadas ao laboratório para o isolamento de Map. As amostras de tecidos foram processadas de acordo com as recomendações da OIE (Manual ..., 2004). Brevemente, 4g de cada tecido foram cortados com lâmina, macerados mecanicamente com pó de vidro e descontaminados com $20 \mathrm{~mL}$ de cloreto de hexadecilpiridínio $0,75 \%$ por $18-24 \mathrm{~h}$. Foi icoculado $0,1 \mathrm{~mL}$ do sedimento em tubos de meio de cultura de Herrold gema de ovo (Herrold's egg yolk medium, HEYM) com micobactina J (Allied Monitor) (Ristow et al., 2006). Os tubos foram incubados por 90 dias, e o crescimento de colônias típicas de Map observado semanalmente. Após o crescimento, foi realizado o teste de dependência da micobactina J e reação da polimerase (PCR), usando-se iniciadores específicos para IS900, conforme descrito anteriormente (Ristow et al., 2007).
À inspeção clínica do animal, era notável o acentuado grau de caquexia. À necroscopia, foram observadas no fígado algumas áreas de telangiectasia. As alças intestinais mostravam-se distendidas, e os linfonodos mesentéricos alongados. Ao corte, os linfonodos apresentavam superfícies cortical e medular normais. Os vasos linfáticos mesentéricos estavam moderadamente dilatados. A mucosa do intestino delgado exibia espessamento e superfície irregular semelhante às circunvoluções cerebrais (cerebroides) (Fig. 1). A válvula ileocecal estava edemaciada, congesta e aumentada em até duas vezes no tamanho normal.

As principais alterações microscópicas estavam no intestino delgado, nos vasos linfáticos, linfonodos mesentéricos e no fígado e incluíam enterite, linfangiectasia, linfadenite e hepatite granulomatosas. No jejuno e no íleo, havia lesões difusas na mucosa e, em algumas áreas, submucosa, caracterizadas por infiltrado de linfócitos, eosinófilos e principalmente macrófagos epitelioides. Havia, ainda, formações incipientes de células gigantes de Langhans. Os macrófagos intestinais estavam repletos de bacilos BAAR em coloração de ZN. Os bacilos formavam grumos no ápice das vilosidades e na região médio glandular, predominantemente, caracterizando uma lesão multibacilar ou lepromatosa. As vilosidades espessadas, algumas vezes, fundiam-se devido, principalmente, à abundância de células epitelioides na mucosa, descaracterizando sua arquitetura. Nos linfonodos mesentéricos, a lesão granulomatosa difusa atingia tanto a medular quanto a cortical, e o infiltrado inflamatório era de macrófagos abundantes, principalmente nos centros germinativos. A coloração de $\mathrm{ZN}$ revelou macrófagos com aglomerados ou globias de BAAR. As lesões hepáticas eram microgranulomatosas e multifocais, com quantidade moderada de células epitelioides, linfócitos e gigantócitos de Langhans contendo BAAR. Com a técnica de IHQ indireta, foi possível visualizar o Map imunoexpressado em marrom-escuro nos citoplasmas dos macrófagos (epitelioides), na mucosa e submucosa intestinais, nos linfonodos e no fígado (Fig. 2) 


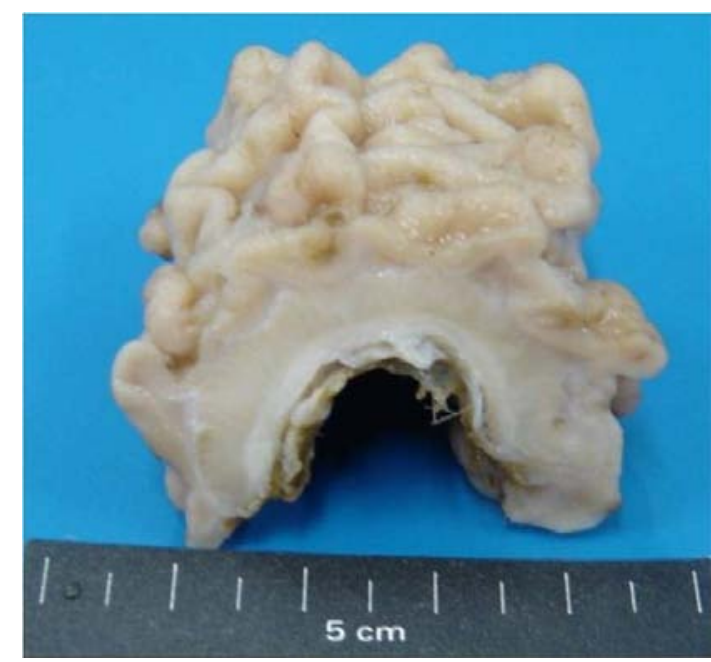

Figura 1. Mucosa ileal de bovino com paratuberculose fixada em formol tamponado neutro a 10\%. Espessamento e corrugação (aspecto cerebroide).

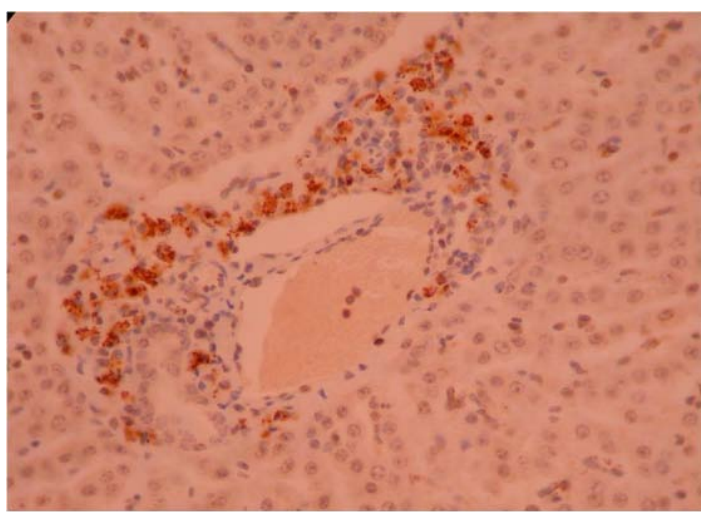

Figura 2. Fotomicrografia mostrando grumos de bacilos imunoexpressados no espaço-porta hepático de bovino com paratuberculose. IHQ, 400X.

As fezes e os tecidos (intestinos, linfonodos mesentéricos e fígado) cultivados em meio HEY com micobactina apresentaram resultados positivos, demonstrando colônias bacterianas típicas de Map. Eram colônias pequenas, brancotranslúcidas, lisas e redondas. A confirmação dos isolamentos deu-se pelo teste de dependência da micobactina J (crescimento apenas em HEY com micobactina e ausência de crescimento sem micobactina) e da PCR IS900 (Ristow et al., 2007).

Os valores referentes à mensuração sérica de AST - 96,6UI/1 - 20 a 34UI/l - e GGT -
21,63UI/l - 6,1 a 17,4UI/l - estavam aumentados quando comparados aos padrões adotados pelo setor de Patologia Clínica do Laboratório de Sanidade Animal da UENF.

Neste relato, a diarreia crônica e o emagrecimento progressivo permitiram suspeitar de paratuberculose, que foi confirmada pela histopatologia e bacteriologia (Ristow et al., 2008). Os sinais clínicos e as alterações macro e microscópicas assemelham-se aos observados em bovinos infectados por Map conforme Chiodini et al. (1984). Segundo Sweeney (1996), a doença leva à síndrome de má absorção provocada pelo processo inflamatório crônico, especialmente na última porção do intestino delgado, no íleo, tendo como consequência graves alterações metabólicas. As lesões granulomatosas com macrófagos repletos de BAAR por toda a mucosa e, algumas vezes, submucosa intestinais, assim como na região cortical e medular dos linfonodos mesentéricos, caracterizaram uma lesão multibacilar ou lepromatosa. Lesões granulomatosas multifocais, contendo macrófagos com razoável número de BAAR, também foram observadas no fígado, confirmando os achados de Driemeier et al. (1999), Mahmoud et al. (2002) e Ristow et al. (2008). Apesar de não ser uma técnica específica para a diferenciação entre as espécies do gênero Mycobacterium spp., a imunoistoquímica foi sensível para a detecção de BAAR nos tecidos (Massone et al., 1990). Seu emprego com imunoglobulinas espécie-específicas foi uma alternativa para o reforço do diagnóstico da paratuberculose, como recomendado por Massone et al. (1990).

A hepatite granulomatosa representou uma resposta à infecção pelo Map, além dos sítios convencionais que são os intestinos e os linfonodos mesentéricos, o comprometimento hepático, mesmo em uma infecção discreta, em relação ao dos outros órgãos lesados, pôde ser confirmado pelas alterações de AST e GGT, duas enzimas implicadas em lesões hepatobiliares. A histopatologia clássica e especial e a imunoistoquímica foram consideradas valiosas no diagnóstico da paratuberculose, sendo uma alternativa ao diagnóstico padrão ouro de cultura bacteriológica.

Palavras-chave: bovino, paratuberculose, hepatite, histopatologia 


\begin{abstract}
Samples from intestines, liver, and lymph nodes were collected from a dairy steer with clinical suspicion of paratuberculosis. The samples were processed for histologic examination with hematoxylin-eosin and Zihel-Neelsen (ZN) staining for the detection of acid-fast bacilli (AFB), and submitted to immunohistochemistry (IHC). Macroscopic changes were observed in the small intestines, with thickening and corrugation of the mucosa. The main microscopic changes were found in small intestines, lymph vessels in the mesentery, and mesenteric lymph nodes characterized by enteritis, lymphangiectasia, and lymphadenitis. Liver presented with granulomatous hepatitis, an uncommon histopathological feature for paratuberculosis. The clinical features associated with positive culture of Mycobacterium avium subsp. paratuberculosis and detection of AFB by ZN and IHC in the cytoplasm of macrophages (epithelioid) in the intestinal mucosa and submucosa, lymph nodes, and liver were important to confirm the diagnosis of paratuberculosis.
\end{abstract}

Keywords: bovine, paratuberculosis, hepatitis, histopathology

\section{AGRADECIMENTOS}

Este estudo foi fomentado pela FAPERJ. Os autores agradecem a Doutora em Ciência Animal da UENF, Luciana da Silva Lemos, ao biólogo Rodrigo Barros Crespo, do Laboratório de Sanidade Animal - UENF e aos técnicos do Laboratório de Micobactérias da UFRJ, Marlei Gomes da Silva e Orlando Marcelino dos Santos.

\section{REFERÊNCIAS BIBLIOGRÁFICAS}

BUERGELT, C.D.; GINN, P.E. The histopathologic diagnosis of subclinical Johne's disease in North American Bison (Bison bison). Vet. Microbiol., v.77, p.325-331, 2000.

CHIODINI, R.J.; VAN KRUININGEN, H.J.; MERKAL, R.S. Ruminant paratuberculosis (Johne's disease): the current status and future prospects. Cornell Vet., v.74, p.218-262, 1984.

DRIEMEIER, D.; CRUZ, C.E.F.; GOMES, M.J.P. et al. Aspectos clínicos e patológicos da paratuberculose em bovinos no Rio Grande do Sul. Pesq. Agropec. Bras., v.19, p.109-115, 1999.

MAHMOUD, O.M.; HAROUN, E.M.; ELFAKI, M.G. et al. Pigmenteed paratuberculosis granulomata in the liver of sheep. Small Ruminant Res., v.43, p.211-217, 2002.

MANUAL of diagnostic tests and vaccines for terrestrial animals. Genebra: OIE/WHO, 2004. Disponível em:

<http://www.oie.int/eng/normes/mmanual/>. Acessado em: 2 dez. 2004.
MASSONE, A.R.; MARTIN, A.A.; IBARGOYEN, G.S. et al. Immunohistochemical methods for the visualization of Mycobacterium paratuberculosis in bovine tissue. J. Vet. Med., v.37, p.251-253, 1990.

RISTOW, P.; SILVA, M.G.; FONSECA, L.S. et al. Evaluation of Mycobacterium avium subsp. paratuberculosis faecal culture protocols and media. Pesq. Vet. Bras., v.26, p.1-4, 2006.

RISTOW, P.; MARASSI, C.D.; RODRIGUES, A.B.F. et al. Diagnosis of paratuberculosis in a dairy herd native to Brazil. Vet. J., v.174, p.432434, 2007.

RISTOW, P.; RODRIGUES, A.B.F.; FONSECA, L.S. et al. Correlation between pathological findings and bacteriological culture on paratuberculous cattle. Cienc. Anim. Bras., v.9, p.700-704, 2008.

ROUSSEL, J.A.; WHITNEY, S.M.; JOLE, J.D. Interpreting a bovine serum chemistry profile; part II. Vet. Med., v.92, p.559-566, 1997

SWEENEY, R.W. Transmission of paratuberculosis. In: SWEENEY R.W. (Ed). Paratuberculosis (Johne's disease). Vet. Clin. N. Am., v.12, p.305-312, 1996. 